\title{
Income Diversification and Bank Performance: Does Bank Size Matter? Empirical Evidence from African Banking Sector
}

\author{
Sofia Benjakik ${ }^{1 *} \quad$ Badr Habba $^{1,2}$ \\ 1.LAREGO Laboratory, ENCG, Cadi Ayyad University, Rue Amerchich, Marrakech 40000, Morocco \\ 2.ESCA School of Management, Rue Abou Youssef El Kindy, Casablanca 20070, Morocco \\ E-mail of the corresponding author: benjakik.sofia@gmail.com
}

\begin{abstract}
This paper investigates the effect of income diversification on bank's risk-adjusted performance. The fixed effect panel regression is used in this study with a panel dataset of 390 banks from 49 different African countries over the period of 2012 to 2019. Our results provide empirical evidence that income diversification increases riskadjusted performance of commercial banks in Africa. However, the relation varies across bank size. Specifically, we find that this relation is stronger at larger banks. In addition, larger banks can make important gains from increasing non-interest income. However, we find limits to diversification benefits at smaller banks in Africa.
\end{abstract}

Keywords: income diversification, non-interest income, bank performance, African banking sector

DOI: $10.7176 /$ RJFA/12-16-03

Publication date:August $31^{\text {st }} 2021$

\section{Introduction}

Since the 1990s, the evolution of the banking industry, due to financial deregulation and increased competition, has led banks to expand their activities and to develop new lines of businesses beside their traditional interest activities (Meslier et al., 2014). Therefore, diversification of income sources to fees, trading, underwriting and cross-selling-based businesses becomes the most prevalent form of bank diversification reducing their dependence on traditional interest income (Stiroh and Rumble, 2006).

The implications of these changes on performance of banks, i.e., risk and profitability, have been mainly addressed for many developed countries but no consensus has been reached at this stage (Meslier et al., 2014). Several studies found that income diversification improved bank performance because mainly non-interest income is less dependent on business conditions than interest income, so an increased dependence on noninterest income decreases the cyclical variation in bank revenue. Further, expand product lines and cross selling opportunities affiliated with growing non-interest income might offer benefits of traditional diversification for a bank's income. If non-interest income and net interest income have a negative or weak correlation, nontraditional income may diversify bank revenue and increase the risk-return trade-off (Stiroh, 2002).

Conversely, DeYoung and Roland (2001) showed that non-interest income enhances the volatility of profits of the banks, due to low switching cost and high operating and financial leverage requirement for fee-based activities. More specifically, banks that rely more on noninterest activities have a higher risk of default than banks that mainly provide loans (Lepetit et al., 2008). Then, if diversified activities are riskier, they risk making bank balance sheets riskier and decrease performance. Thus, income diversification based on non-interest activities can bring risks for which specialized managerial expertise are required or may adversely affect the performance (Sahoo and Mishra, 2012).

Besides the inconclusive results in the previous literature, the empirical evidence documented on diversification in the banking sector is heavily concentrated in U.S. and many other developed countries, with much less insight in emerging or transitional economies (Berger et al., 2010). However, the focus on Africa was unhurried despite of the amazing background provided by the developments in African banking industry for such investigations (Boadi, 2018). Thus, our research attempts to fill this gap in the literature by studying the effect of income diversification in the world's second-largest and second-most populous continent.

The remainder of the paper is structured as follows. Section 2 Presents recent trends in the income structure of the African banking industry. Section 3 provide a short review of the theoretical and empirical literature on the nexus between income diversification and bank performance. Section 4 describes the data, variables and the empirical model used in our analysis. Section 5 presents and discusses our empirical results. Section 6 summarizes the findings and concludes the paper. 


\section{African banking sector and income diversification}

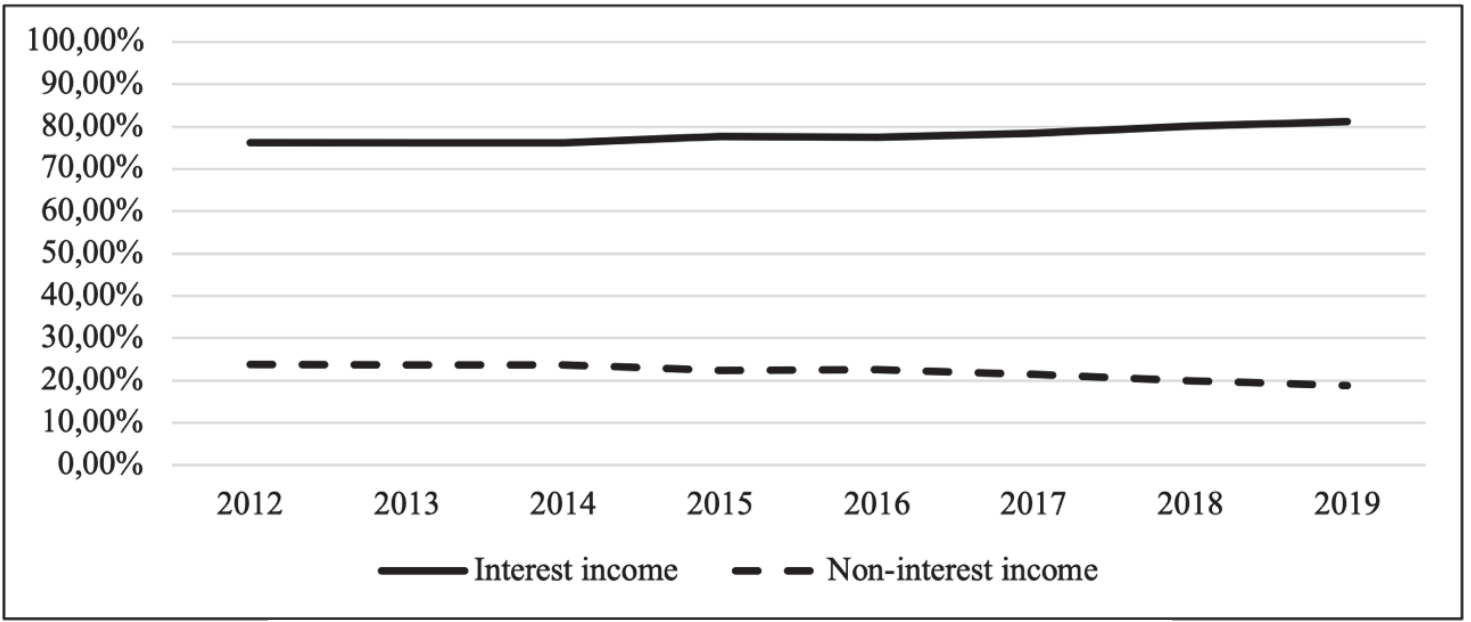

Figure 1. Interest income and non-interest income as percentage

of operating income in African banking sector (2012-2019)

The African banking sector, like other emerging and developing economic regions, has undergone significant regulatory and structural changes since the 1980s following a long period of underperformance (Apergis, 2015; M. Nguyen et al., 2016). These financial reforms aimed at improving performance of banks and fostering competition encouraged African banks to the expansion of their banking models and diversification of their range of financial services (Claessens and Van Horen, 2014; Léon, 2016). These reform packages have specifically brought attention to the generation of non-traditional income i.e. fees, transaction fees, annual and monthly account service charges, inactivity fees, check and deposit slip fees and so on in many African countries (Boadi, 2018).

Figure 1 indicates the trend of the non-interest income share in African banking sector over the period of 2012-2019. In fact, the figure shows an increase of interest income's share from on average of 76 percent in 2012 compared to 81 percent in 2019, While the share of non-interest income, on average, has deceased from 24 percent in 2012 to only 19 percent in 2019. Thus, the African banking sector strongly depends on income from traditional banking activities in lending. This suggests that as far as Africa's banking environment is concerned, a high percentage of banks' revenue is generated from interest income from loans and advances as compared to the revenue from non-traditional activities.

According to the World Bank's World Development Indicators, most African countries are characterized by shallow banking systems that often offer little more than basic banking services despite marked improvements over the last decade (Beck and Cull, 2013). This shallow financial markets in Africa are often explained by the simultaneous presence of four adverse characteristics of African economies and societies (Beck and Cull, 2013; Honohan and Beck, 2007). While shallow, African banking systems have also proven stable and resilient over the past years, thanks to regulatory upgrades in most African countries and the high capitalization and liquidity levels of banks. The shallowness of Africa's banking systems appears to have helped them weather the Global Financial Crisis of 2008 better than some other regions of the world.

\section{Theoretical background and literature review}

\subsection{Theoretical issues}

Theoretically, the issue of "focus » versus "diversification 》 is well documented in the corporate finance literature, although a general consensus has not been achieved (Berger et al., 2010).

In fact, proponents of "diversification » suggest that diversified banks can bring important benefits in the forms of higher profitability (Chiorazzo et al., 2008; DeYoung and Roland, 2001), gaining economies of scope (Meslier et al., 2014; Saunders and Walter, 1994), lower monitoring costs, make efficient use of management skills (Drucker and Puri, 2009), reduce risk by broadening operations across diverse products and different geographical regions (Boyd and Graham, 1986) and greater potentialities to extend competitive opportunities when going in for new markets (Amidu and Wolfe, 2013; Elsas et al., 2010).

Despite the potential benefits of diversification, proponents of « strategic focus hypothesis » argue that companies can maximize their value by focusing on core businesses and core competencies (Berger, 1999). In fact, Amihud and Lev (1981) suggest that conglomeration can reflect agency problems in which managers may add businesses to protect the value of their human capital, or rise their private benefits (Jensen, 1986). As a result, diversification can increase agency costs resulting from value-decreasing activities of the managers who have lowered their personal risk (Amihud and Lev, 1981; Deng and Elyasiani, 2008; Laeven and Levine, 2007) and 
increasing the volatility of profits (De Jonghe, 2010; DeYoung and Roland, 2001; Stiroh, 2004b).

In the final analysis, the conclusion is still inconclusive. Therefore, whether a general strategy of diversification enhances bank performance becomes an empirical question.

\subsection{Empirical evidence}

Empirically, studies have examined the issue of diversification benefits from several standpoints and through different methodological approaches. Early research tends to investigate the influence of diversification on bank profitability (e.g., Trujillo-Ponce, 2013; Chronopoulos et al., 2015; Ismail et al., 2015) or on the bank value (e.g., Baele et al., 2007; Elsas et al., 2010; Guerry and Wallmeier, 2017). Recently, the accounting approach has become the main method that researchers use to identify the effects of diversification on performance.

The existing empirical results provide mixed results about the impact of diversification on bank performance. Some studies suggest that diversification tends to increase its exposure to risk and impair the riskreturn trade off (Deyoung and Rice, 2004; Lepetit et al., 2008; Nurullah and Staikouras, 2008; Stiroh, 2004a; Stiroh and Rumble, 2006). These results are consistent with Laeven and Levine (2007) who show that the market values of financial conglomerates (including BHCs) operating in 43 countries from 1998 to 2002 that engage in multiple activities are lower than when each product is produced by a separate financial operator. The findings support the perspective that conglomerates amplify agency problems, which eliminate the positive effects of economies of scope connected to diversification strategies.

Other studies have provided evidence of a positive impact of diversification on bank performance. For instance, Elsas et al. (2010) investigate an international sample of banks from 9 countries over the period of 1996 to 2008 to test the effects of revenue diversification on bank value. The results show that a larger share of noninterest income improve bank profitability and hence bank stock prices, even during the financial crisis of 20072008. Further, diversification of revenue from distinct activities increases the systematic risk and generally decreases idiosyncratic risk. Similarly, Baele et al. (2007) investigate the influence of functional diversification on bank return and risk using a panel dataset of 143 banks active in 17 European Union over the period 19892004, and confirm that banks with a higher share of non-interest income have higher market values. In another cross-country analysis conducted for a sample of listed banks from 11 emerging countries, Sanya and Wolfe (2011) who show evidence that income diversification as well as within both types of activities increases profitability and reduces bank insolvency risk of emerging market banks.

On the other side, some studies have reported mixed results. Mercieca et al. (2007) examine the effect of diversification on average profitability by calculating the effect of an increase in the non-interest share of activities using a sample of 755 small European banks from 15 countries between 1997 to 2003. They find that an increase in non-interest activities has produced two main sorts of effects: direct consequences of shifting to non-interest activities and indirect effects arising from changes in diversification. Moreover, a negative net effect is observed for average profitability, whereas a corresponding positive effect is detected for volatility. The authors find evidence to suggest that the higher volatility of net-interest income outweighs the benefits of diversification, are robust to several additional controls over the investigated period.

More recently, Shweta and Anand (2018) analyze the effect of diversification on performance on unbalanced panel data set of 169 BRICS banks between 2001 and 2015. The authors provide evidence of a significant effect of diversification on enhancing bank returns and reducing risk for banks with medium and large size. However, they find a diversification discount for small banks, which reject the "one-size-fits-all" approach of regulators and policy makers ${ }^{1}$. Conversely, for an efficient strategy of diversification, they suggest to focus on improving performance through the development business along with minimizing the risk carrying out of those exposures.

While a massive number of papers investigated the link between income diversification and bank performance in the case of developed economies, only few papers analysed this issue in the case of banks in Africa. Among these studies, Olarewaju (2017) examine the effect of operational diversification on performance of banks by calculating the Herfindahl Hischman index using a sample of 250 commercial banks, from 30 SubSaharian Africa countries over the period 2006 to 2015. The analysis suggests that diversification of operational activities have direct and significant effect on financial performance. Using the stochastic frontier analysis (SFA) on sample of Ghanaian banks between 2003 and 2011, Alhassan (2015) found a non-linear relationship between income diversification, and cost and profit efficiency of banks. The author emphasize that bank size enables banks to get the benefits of income diversification.

\section{Data and methodology}

In this section, we define the different variables in the analysis, then we describe our database and our empirical model.

\footnotetext{
${ }^{1}$ This approach recommends DIV as a tool to improve bank performance
} 


\subsection{Data}

We obtain detailed annual income and balance sheet data for banks in Africa from Bureau van Dijk's BankFocus disk, over the period 2012 to 2019 (8 years). We construct our sample using three criteria: (1) First, we exclude companies with no recent financial data and public authorities/States/Governments. Further, (2) we purge the sample of banks which we do not classify as commercial banks. Lastly, (3) we exclude the IIs and NIIs with negative values. At the end, our final sample consists 390 commercial banks operating in all regions of Africa.

Figure 2. Sample distribution by country

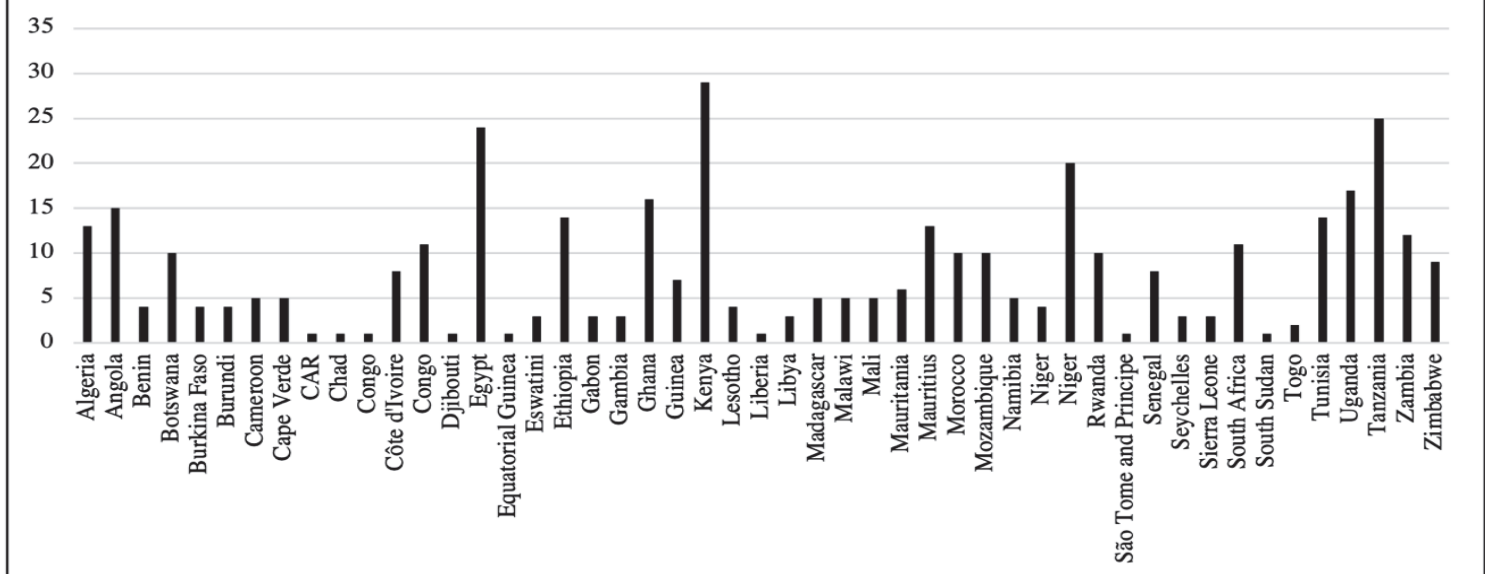

\subsection{Methodology}

To evaluate the effect of income diversification on bank's performance in Africa, this study proceeds in three steps: first, measuring banks' degree of diversification; second, measuring their risk-adjusted performance; and third, explaining the relation between diversification and risk-adjusted performance. Therefore, we base our empirical analysis on a set of variables that includes an index of diversification, measures of bank performance, and several control variables.

\subsubsection{Diversification measures}

For income diversification, we use an indexation approach following previous studies such as Chiorazzo et al. (2008); Sanya and Wolfe (2011) and Stiroh (2004). First, we consider that there are two types of income IIs which we measure as interest income/operating income; NIIs measured as non-interest income/operating income.

$$
\begin{gathered}
I I S=\frac{I I}{N O I} \\
N I I S=\frac{N I I}{N O I}
\end{gathered}
$$

Then, we use (1) and (2) to compute a Herfindahl-Hirschman Index (HHI) of income specialization to define our measure of income diversification (Chiorazzo et al., 2008; Stiroh and Rumble, 2006):

$$
\operatorname{Div}=1-\left(I I s^{2}+N I I s^{2}\right)
$$

As the diversification index varies from 0.0 to 0.5 , we exclude the IIs and NIIs with negative values. In fact, index value of 0.5 represents complete diversification, while index value of 0 indicates the lowest level of diversification ${ }^{1}$.

4.2.2 Risk-adjusted performance measures

Meanwhile, we use the most widely used indicators for measuring bank performance: Return on assets (ROA) and Return on equity (ROE). In fact, to mitigate asset and equity changes during the year, we use ROAA (Return On Average Assets) and ROAE (Return On Average Equity).

Thus, following Chiorazzo et al. (2008), we define our bank performance indicators as the ratio between the annual return and its standard deviation to adjust these measures for risk:

$$
\text { SHROAA }_{i t}=\frac{\text { ROAA }_{i t}}{\sigma \mathrm{ROAA}_{\mathrm{i}}}
$$

\footnotetext{
${ }^{1}$ This measure is similar to the Herfindahl - Hirschman concentration index, except that the interpretation is reversed. Here, a higher number indicates a higher diversification and less concentration of activities.
} 


$$
\mathrm{SHROAE}_{i \mathrm{t}}=\frac{\mathrm{ROAE}_{\text {it }}}{\sigma \mathrm{ROAE}_{\mathrm{i}}}
$$

Where SHROAA ${ }_{i t}$ and $\mathrm{SHROAE}_{\text {it }}$ indicate risk-adjusted performance, respectively, in terms of ROAA and ROAE, for the bank $i$ in the year $t$.

4.2.3 Control variables

To capture effects of bank-specific exogenous variables, we use four control variables in order to enrich our econometric model. These variables are reputed to have a significant influence on the bank's performance.

First, ASSETS variable is the natural logarithm of bank assets. Following the previous literature (Chiorazzo et al., 2008; Meslier et al., 2014; Stiroh \& Rumble, 2006), this control variable captures the effects of bank size in our regression analysis. Larger banks may be better in risk management, more advanced technologies and diversification opportunities. Conversely, small banks are more flexible in their operations (Chiorazzo et al., 2008; Deyoung and Rice, 2004; Sanya and Wolfe, 2011). Therefore, we expect a positive sign for the relationship between size bank and risk-adjusted performance.

Second, GROWTH variable is the annual growth rate of bank assets. In fact, this variable is our proxy for the bank managers' risk-taking preference. A high growth rate refers to a high risk-taking attitude (Chiorazzo et al., 2008; Stiroh, 2004b).

Third, EQUITY variable is the ratio of equity to bank assets, this variable represents the degree of financial leverage of bank and refers to risk aversion of a bank (Chiorazzo et al., 2008; M. Nguyen et al., 2016; Sanya and Wolfe, 2011; Stiroh, 2004b).

Fourth, LOANS variable is the ratio of total loans to bank assets. This variable captures the effects of lending strategy on risk-adjusted bank returns (Chiorazzo et al., 2008; Sanya and Wolfe, 2011; Stiroh, 2004b).

Table 1. Variables' descriptions and sources used

\begin{tabular}{|c|c|c|c|}
\hline Classification & Variable & Description & Source \\
\hline \multirow{4}{*}{$\begin{array}{l}\text { Dependent } \\
\text { variable }\end{array}$} & ROAA & Return on average assets & BankFocus \\
\hline & ROAE & Return on average equity & \\
\hline & SHROAA & $\begin{array}{l}\text { Ratio between ROAA and standard deviation of ROAA } \\
\text { over the period 2012-2019 }\end{array}$ & $\begin{array}{l}\text { Authors' calculation } \\
\text { based on BankFocus }\end{array}$ \\
\hline & SHROAE & $\begin{array}{l}\text { Ratio between ROAE and standard deviation of ROAE } \\
\text { over the period 2012-2019 }\end{array}$ & \\
\hline \multirow[t]{2}{*}{$\begin{array}{l}\text { Income } \\
\text { diversification }\end{array}$} & Div & $\begin{array}{l}\text { One minus the sum of the square of the share of net } \\
\text { interest income over net operating income and the share } \\
\text { of net non-interest income over net operating income }\end{array}$ & $\begin{array}{l}\text { Authors' calculation } \\
\text { based on BankFocus }\end{array}$ \\
\hline & NIIs & Share of non-interest income over net operating income & $\begin{array}{l}\text { Authors' calculation } \\
\text { based on BankFocus }\end{array}$ \\
\hline \multirow{4}{*}{$\begin{array}{l}\text { Control } \\
\text { variables }\end{array}$} & ASSETS & Natural logarithm of bank total assets & BankFocus \\
\hline & GROWTH & Annual growth rate of bank assets & \\
\hline & LOANS & Ratio of loans to total assets & \\
\hline & EQUITY & $\begin{array}{l}\text { Capitalization ratio, measured as the ratio of equity to } \\
\text { total assets. }\end{array}$ & \\
\hline
\end{tabular}

4.2.4 Estimation model

Following the existing literature, we consider the effect of income diversification on bank performance including year and bank fixed effect in panel-data regression estimation.

Specifically, the aim of this research is to investigate whether, and to what extent, non-interest income affects the risk-adjusted performance measures. Therefore, we developed our model based on earlier studies such as Chiorazzo et al. (2008). For robustness reason, we estimate the econometric model with two measures of performance. We use risk adjusted return on assets, and risk-adjusted return on equity as the proxy. The two models can be described by the following equations, in which $\mathrm{Y}=$ [ SHROAA, SHROAE] are the dependent variables:

$$
\begin{gathered}
\mathrm{Y}_{\mathrm{i}, \mathrm{t}}=\mathrm{k}+\alpha_{\mathrm{t}}+\varphi_{\mathrm{i}}+\beta_{1} \operatorname{Div}_{\mathrm{i}, \mathrm{t}}+\delta_{1} \operatorname{ASSETS}_{\mathrm{i} ; \mathrm{t}}+\delta_{2} \operatorname{GROWTH}_{\mathrm{i} ; \mathrm{t}}+\delta_{3} \text { EQUITY }_{\mathrm{i}, \mathrm{t}}+\delta_{3} \operatorname{LOANS}_{\mathrm{i}, \mathrm{t}}+\mathrm{v}_{\mathrm{i}, \mathrm{t}} \\
\mathrm{i}=1, \ldots, 390, \mathrm{t}=2012, \ldots, 2019
\end{gathered}
$$

Where $\mathrm{Y}$ is a measure of risk-adjusted returns (SHROAA, SHROAE), $\mathrm{k}$ is a constant, $\alpha$ is a time fixed effect, and $\varphi$ is a bank fixed effect. As in Stiroh and Rumble (2006) and in Chiorazzo et al. (2008), we note that $\beta_{1}$ represents the effect of income diversification between interest income and non-interest income; positive values of $\beta_{1}$ indicate that income diversity leads to higher risk-adjusted returns. 


\section{Empirical results and discussion}

\subsection{Descriptive Statistics}

Table 2 reports the descriptive statistics for SHROAA, SHROAE, income diversification and also some banklevel characteristics variables, including size variables and risk proxies for all the banks during the sample period 2012-2019. These variables follow the definitions provided in Section 4.

Overall, the mean and median of most variables is close enough. It shows the distribution of data is good. First, the reported values reveal that during 2012 and 2019, the overall mean value of African banks SHROAA and SHROAE were equal to 3.578 and 3.535 respectively.

Second, we use the diversification index to identify differences in operating activities between banks. Table 2 indicates the variation across African banks. Meanwhile, the income diversification of banks is averagely at 36.60 percent and range from 0 (complete concentration) to 0.5 (full diversification), which indicates that most of banks in Africa did not fully diversify their income. Further, we observe that smaller banks are comparatively more diversified as compared to their smaller counterparts, with an average of 37.20 percent in smaller banks and 36 percent in larger banks.

Third, the mean value of asset growth rate (GROWTH) in commercial banks in Africa over the period 2012 -2019 is relatively low in larger banks (0.074) comparatively with smaller banks (0.131). Also, the mean value of EQUITY variable (equity/total assets) is relatively high (14.397) during the sample period as a result of strictly regulated environment of African banking sector. LOANS variable has the mean of lower than 50 percent (0.468) which may indicate conservative risk attitude of African managers as whole and again an indicator of strict regulatory rules in African banking sector.

Table 2. Summary Statistics and Definitions of Variables $(2012-2019)$

\begin{tabular}{|c|c|c|c|c|c|c|}
\hline Variable & Obs. & Mean & Std. Dev. & Median & Min & Max \\
\hline \multicolumn{7}{|c|}{ Summary statistics for all observations } \\
\hline \multicolumn{7}{|c|}{ Performance measures } \\
\hline SHROAA & 2,420 & 3.578 & 4.397 & 2.692 & -17.054 & 52.847 \\
\hline SHROAE & 2,407 & 3.535 & 4.338 & 2.658 & -18.542 & 40.910 \\
\hline \multicolumn{7}{|c|}{ Income diversification } \\
\hline DIV & 2,658 & 0.366 & 0.113 & 0.391 & 0.000 & 0.500 \\
\hline \multicolumn{7}{|c|}{ Control variables } \\
\hline ASSETS & 2,686 & 13.459 & 1.667 & 13.330 & 8.980 & 18.563 \\
\hline GROWTH & 2,429 & 0.100 & 0.359 & 0.066 & -0.970 & 8.182 \\
\hline LOANS & 2,672 & 0.468 & 0.183 & 0.483 & 0.000 & 0.934 \\
\hline EQUITY & 2,684 & 14.408 & 10.512 & 12.358 & -95.156 & 99.080 \\
\hline \multicolumn{7}{|c|}{ Summary statistics for smaller banks: } \\
\hline \multicolumn{7}{|c|}{ Performance measures } \\
\hline SHROA & 1,090 & 2.312 & 3.563 & 1.510 & -17.054 & 23.254 \\
\hline SHROE & 1,086 & 2.305 & 3.809 & 1.481 & -18.542 & 28.281 \\
\hline \multicolumn{7}{|c|}{ Income diversification } \\
\hline DIV & 1,256 & 0.372 & 0.113 & 0.401 & 0 & 0.5 \\
\hline \multicolumn{7}{|c|}{ Control variables } \\
\hline ASSETS & 1,265 & 12.117 & 0.895 & 12.239 & 8.980 & 15.588 \\
\hline GROWTH & 1,094 & 0.131 & 0.407 & 0.077 & -0.970 & 6.838 \\
\hline LOANS & 1,255 & 0.435 & 0.194 & 0.451 & 0 & 0.934 \\
\hline EQUITY & 1,264 & 17.678 & 12.305 & 14.730 & -38.633 & 97.749 \\
\hline \multicolumn{7}{|c|}{ Summary statistics for large banks: } \\
\hline \multicolumn{7}{|c|}{ Performance measures } \\
\hline SHROA & 1,330 & 4.615 & 4.732 & 3.564 & -2.615 & 52.847 \\
\hline SHROE & 1,321 & 4.546 & 4.483 & 3.517 & -2.493 & 40.910 \\
\hline \multicolumn{7}{|c|}{ Income diversification } \\
\hline DIV & 1,402 & 0.360 & 0.112 & 0.383 & 0.003 & 0.5 \\
\hline \multicolumn{7}{|c|}{ Control variables } \\
\hline ASSETS & 1,422 & 14.652 & 1.230 & 14.448 & 10.416 & 18.563 \\
\hline GROWTH & 1,335 & 0.074 & 0.320 & 0.061 & -0.683 & 8.182 \\
\hline LOANS & 1,417 & 0.497 & 0.166 & 0.503 & -0.001 & 0.899 \\
\hline EQUITY & 1,420 & 11.497 & 7.494 & 10.836 & -95.156 & 99.08 \\
\hline
\end{tabular}

Note: For a definition of the variables, see Table 1. 


\subsection{Correlation analysis}

Table 3 provides the correlation matrix for the variables included in the paper. The two measures of risk-adjusted performance have a strong positive correlation of 0.8551 which is statistically significant. In addition, we calculated the variance inflation factor (VIF) statistics for the previous regression model to quantify the severity of multicollinearity in our model. As a result, the test does not suggest that any variables should be dropped from our regression as the VIF statistics are within the specified range.

Table 3. Correlation matrix

\begin{tabular}{|c|c|c|c|c|c|c|c|}
\hline & DIV & SHROAA & SHROAE & ASSETS & GROWTH & LOANS & EQUITY \\
\hline DIV & 1.0000 & & & & & & \\
\hline SHROAA & 0.0411 & 1.0000 & & & & & \\
\hline SHROAE & 0.0687 & 0.8551 & 1.0000 & & & & \\
\hline ASSETS & -0.1015 & 0.3817 & 0.3756 & 1.0000 & & & \\
\hline GROWTH & 0.0617 & -0.0320 & -0.0321 & -0.0614 & 1.0000 & & \\
\hline LOANS & -0.0195 & 0.1373 & 0.1263 & 0.1668 & -0.1290 & 1.0000 & \\
\hline EQUITY & -0.0720 & -0.0899 & -0.1027 & -0.4099 & -0.0058 & -0.1748 & 1.0000 \\
\hline
\end{tabular}

Source: Author's Computation

\subsection{Hausman test}

In an attempt to know the most reliable estimation between the fixed effect estimation and the random effect estimation, Hausman test is conducted to test if there is a substantial difference between the estimates of the fixed effect estimator and that of the random effect estimator.

Table 4. Hausman Test of FEM and REM

Ho: difference in coefficients not systematic

\begin{tabular}{|l|l|l|}
\hline Test-estimate & Chi-square statistics & Probability \\
\hline chi2 $(5)=(\mathrm{b}-\mathrm{B})^{\prime}\left[(\mathrm{V} \mathrm{b}-\mathrm{V} \mathrm{B})^{\wedge}(-1)\right](\mathrm{b}-\mathrm{B})$ & 33.23 & 0.0000
\end{tabular}

Source: Author's Computation. $b=$ consistent under Ho and Ha; obtained from xtreg $B=$ inconsistent under Ha, efficient under Ho; obtained from xtreg

From the table above, chi-square value of 33.23 and the P-value provided by the Hausman test 0.0000 (less than 0.05), shows that there is enough evidence to reject the null hypothesis. Then, the difference in coefficients is unsystematic and highly substantial. This implies that there is correlation between the random effects incorporated into the composite error term and one or more of the independent variables. Thus, the FEM estimation becomes the best model that is most efficient, consistent and preferred, while REM estimation is considered inefficient.

5.3 Income diversification and bank performance - regression results

Table 5 presents the estimation based on the fixed effect model to estimate the impact of income diversification on bank performance. Columns 1 show the results of SHROAA as a dependent variable while columns 2 depict the results for SHROAE. 
Table 5. Income diversification and bank risk-adjusted performance (fixed effects model)

\begin{tabular}{lcc}
\hline Variable & $(1)$ & $(2)$ \\
& SHROAA & SHROAE \\
\hline DIV & $1.147^{* *}$ & $1.167 * *$ \\
ASSETS & $(3.07)$ & $(3.08)$ \\
& $0.287^{* *}$ & $0.500^{* * *}$ \\
GROWTH & $(3.14)$ & $(5.03)$ \\
& -0.00594 & -0.0705 \\
LOANS & $(-0.09)$ & $(-0.88)$ \\
& 0.301 & 0.224 \\
EQUITY & $(1.00)$ & $(0.72)$ \\
& $0.0386 * * *$ & $0.0166^{* *}$ \\
cons & $(7.57)$ & $(2.61)$ \\
& -1.372 & $-3.975^{* *}$ \\
$\mathrm{~N}$ & $(-1.06)$ & $(-2.79)$ \\
R-square & 2,396 & 2,385 \\
$Y_{i, t}=k+\propto_{t}+\varphi_{i}+\beta_{1}$ Div $_{i, t}+\delta_{1}$ ASSETS $_{i ; t}+\delta_{2}$ GROWTH & 0.1574 \\
$1, \ldots, 390, t=2012, \ldots, 2019$, & & 0.1274
\end{tabular}

Notes: this table reports estimates of the following fixed effects model:

where Y is equal to Sharpe's Ratios for ROAE (SHROAE) and for ROAA (SHROAA) in models (1) and

(2) respectively; DIV- income diversification index; ASSETS- bank assets; GROWTH- growth rate of bank

assets; LOANS- share of loans on bank assets; EQUITY - share of equity on bank assets;

$\mathrm{t}$ statistics in parentheses $* \mathrm{p}<0.05, * * \mathrm{p}<0.01, * * * \mathrm{p}<0.001$

Source: Authors' computation

Overall, the outputs of both regressions show identical results that could be summarized as follows: As observed in Table 5, income diversification has a significant relationship with bank performance in both models. In SHROA model, DIV index has a significant coefficient value of 1.147. The same conclusion is found in SHROE model, where DIV has a coefficient value of 1.167. Therefore, the findings suggest that generally, income diversification positively affects the profitability of banks by improving risk-adjusted returns, which is in line with the prior studies such as Brahmana et al., (2018), Chiorazzo et al. (2008), Meslier et al. (2014) and Stiroh and Rumble (2006). Therefore, this finding generally supports the view that banks benefit from economies of scope when they diversify their income (Klein and Saidenberg, 1997).

In terms of control variables, we find that bank size, ASSETS, measured by the natural logarithm of bank assets contribute significantly on risk-adjusted performance in Africa. Our finding on the positive relationship between banks size and risk-adjusted performance is well proved in the literature (Demsetz and Strahan, 1997; Deyoung and Rice, 2004; Sanya and Wolfe, 2011).

In addition, our findings suggests that an increase in bank capitalization, EQUITY, increases risk-adjusted profits with coefficient values of 0.0386 and 0.0166 for SHROAE and SHROAA respectively. Our results are consistent with Stiroh (2004) and Al-Tarawneh et al. (2016) and the conventional view which asserts that high levels of capitalization will reduce risk by placing banks in a better position to absorb losses. As well, wellcapitalized banks usually have lower costs of funding to support due to lower bankruptcy costs so if banks are faced with lower profitability, they may reduce buffer capital and utilize those funds to diversify into riskier but more profitable sources of income to reduce future costs of funding (Pennathur et al., 2012). In the same way, banks which pay less interest due to strong capital structure can benefit from competition advantage then increase performance (Al-Tarawneh et al., 2016) suggesting that the increase of equity to total assets is beneficial to enhance the stability of commercial banks (Bian et al., 2015). Consequently, the strength and quality of capital will influence the bank performance.

However, we do not find any significant relation between lending activity, LOANS, and riskadjusted performance. Our results are consistent with the results found by Deyoung and Rice (2004) and Meslier et al. (2014) but differ from those of Chiorazzo et al. (2008) who discover a positive effect of increased loans on riskadjusted performance.

To check how the income diversification interacts with bank size, in eq. 6 with SHROAA as SHROAE dependent variables we perform an additional test that addresses the bank size issue. Using the same methodology described in previous section, we re-estimate the previous model for two subsamples: the smaller and the larger banks of the sample. We rank our sample of 390 banks on the basis of their average size and divide it into two groups obtaining 195 smaller banks and 195 larger banks. 
Table 6. Income diversification and risk-adjusted performance in larger and smaller banks

\begin{tabular}{|c|c|c|c|c|}
\hline \multirow[b]{2}{*}{ Variable } & \multicolumn{2}{|c|}{ Dependent variable: SHROAA } & \multicolumn{2}{|c|}{ Dependent variable: SHROAE } \\
\hline & Smaller banks & $\begin{array}{c}\text { (5) } \\
\text { Larger banks }\end{array}$ & Smaller banks & $\begin{array}{c}\text { (6) } \\
\text { Larger banks }\end{array}$ \\
\hline DIV & $\begin{array}{l}-0.149 \\
(-0.29)\end{array}$ & $\begin{array}{c}2.442 * * * \\
(4.57)\end{array}$ & $\begin{array}{l}0.201 \\
(0.39)\end{array}$ & $\begin{array}{c}2.233 * * * \\
(4.05)\end{array}$ \\
\hline ASSETS & $\begin{array}{l}0.821 * * * \\
\quad(6.40)\end{array}$ & $\begin{array}{c}-0.278 * \\
(3.93)\end{array}$ & $\begin{array}{l}0.983 * * * \\
(8.00)\end{array}$ & $\begin{array}{c}-0.0209 \\
(-0.14)\end{array}$ \\
\hline GROWTH & $\begin{array}{l}-0.150 \\
(-1.59)\end{array}$ & $\begin{array}{c}-0.0170 \\
(-0.17)\end{array}$ & $\begin{array}{c}-0.0239 * \\
(-2.57)\end{array}$ & $\begin{array}{c}-0.0827 \\
(0.55)\end{array}$ \\
\hline LOANS & $\begin{array}{l}0.522 \\
(1.31)\end{array}$ & $\begin{array}{l}0.288 \\
(0.62)\end{array}$ & $\begin{array}{l}0.194 \\
(0.50)\end{array}$ & $\begin{array}{l}0.556 \\
(1.15)\end{array}$ \\
\hline EQUITY & $\begin{array}{l}0.0437 * * * \\
\quad(7.57)\end{array}$ & $\begin{array}{l}0.0369 * * * \\
\quad(5.12)\end{array}$ & $\begin{array}{l}0.0221 * * \\
(3.26)\end{array}$ & $\begin{array}{c}-0.0102 \\
(0.70)\end{array}$ \\
\hline _cons & $\begin{array}{c}-8.582 * * * \\
(-5.20)\end{array}$ & $\begin{array}{l}7.291 * * * \\
(3.57)\end{array}$ & $\begin{array}{c}-10.17 * * * \\
(-6.35)\end{array}$ & $\begin{array}{l}3.921 \\
(1.68)\end{array}$ \\
\hline $\mathrm{N}$ & 1,082 & 1,314 & 1,078 & 1,307 \\
\hline R-Square & 0.1733 & 0.1494 & 0.1601 & 0.1170 \\
\hline
\end{tabular}

Notes: this table reports estimates of the following

models ${ }^{1}$ :

$Y_{i . t}=k+\propto_{t}+\varphi_{i}+\beta_{1}$ DIV $_{i . t}+\delta_{1}$ ASSETS $_{i: t}+\delta_{2}$ GROWTH $_{i: t}+\delta_{3}$ EQUITY $_{i: t}+\delta_{4}$ LOANS $_{i: t}+v_{i, t} i=1, \ldots, 390, t=2012, \ldots, 2019$ . Model $(3,4)$ comprises the banks with an average bank assets during the period 2019 that are lower than the median value of ASSETS. Models (5,6) comprises the banks with an average bank assets, during 2019 that are equal or higher than the median value of ASSETS. t statistics in parentheses $* \mathrm{p}<0.05, * * \mathrm{p}<0.01, * * * \mathrm{p}<0.001$ Source: Authors' computation

Several empirical research studies argue that the potential benefits/disadvantages from diversification may diverge because of banks size. When we examine the subsample of smaller banks and larger banks, we find that for banks with large asset size, income diversification has a strong positive effect on bank risk-adjusted performance. Specifically, this finding confirms that larger banks showed greater diversification benefits than smaller banks. Our results are aligned with the results of Shweta and Anand (2018), which reported that as the size of bank increases, efficient diversification strategies are being adopted to control for concentration risk. However, our results are in contrast with those of Barros et al. (2007), which suggest that larger sized and more diversified banks are more likely to perform poorly, suggesting that smaller sized and specialized banks can reduce asymmetric information problems associated with lending.

Thus, our findings may suggest that larger banks are better able to enjoy scale economies in risk management, easier access to capital markets and "too big to fail" protections, could exacerbate banks' risk attitude (Brighi and Venturelli, 2014). In addition, the reason for our finding on size may be the fact that larger banks generally have better information technology, human capital, geographical diversification and lower cost of capital that gives larger banks a competitive edge. Besides, this result may also suggest that African banks are able to exploit scale economies and have efficient risk management techniques.

However, we find in Table 6 that ASSETS variable has a positive effect on risk-adjusted returns in smaller banks but a negative and non-significant impact in larger banks. In fact, we suggest the existence of an optimal size. As size increases risk-adjusted performance increase up to an optimal mid-point. After a given threshold of size, any further increases in bank size leads to a gradual decrease in risk-adjusted performance of African banks.

5.4 Robustness tests results: Alternative measure of income diversification

In this section, we employ a more direct measure of income diversification, which is the ratio of non-interest income to bank total operating income (NIIs), to obtain a more comprehensive understanding of the effect of income diversification on bank performance. SHROAA and SHROAE are still used as proxies for bank

\footnotetext{
${ }^{1}$ After using Hausman test, we use the fixed effect for model (3), (5), (6) and random effect for model (4).
} 
performance. With regard to methodology, we continue to adopt the fixed effect model after applying the Hausman test.

Table 7. Robustness check- Alternative measure of diversification

\begin{tabular}{|c|c|c|c|c|c|c|}
\hline \multirow[b]{2}{*}{ Variable } & \multicolumn{3}{|c|}{ Dependent variable: SHROAA } & \multicolumn{3}{|c|}{ Dependent variable: SHROAE } \\
\hline & $\begin{array}{c}\text { (1) } \\
\text { Overall }\end{array}$ & $\begin{array}{c}\text { (2) } \\
\text { Smaller banks }\end{array}$ & $\begin{array}{c}\text { (3) } \\
\text { Larger banks }\end{array}$ & $\begin{array}{c}\text { (4) } \\
\text { Overall }\end{array}$ & $\begin{array}{c}(5) \\
\text { Smaller } \\
\text { banks }\end{array}$ & $\begin{array}{c}\text { (6) } \\
\text { Larger } \\
\text { banks }\end{array}$ \\
\hline NII & $\begin{array}{c}1.469 * * * \\
(5.18)\end{array}$ & $\begin{array}{l}0.883^{*} \\
(2.32)\end{array}$ & $\begin{array}{c}2.031 * * * \\
(4.83)\end{array}$ & $\begin{array}{c}1.295^{* * *} \\
(4.51)\end{array}$ & $\begin{array}{l}0.671 \\
(1.79)\end{array}$ & $\begin{array}{c}1.862 * * * \\
(4.28)\end{array}$ \\
\hline ASSETS & $\begin{array}{c}0.342 * * * \\
(3.73)\end{array}$ & $\begin{array}{c}0.861 * * * \\
(6.72)\end{array}$ & $\begin{array}{l}-0.220 \\
(-1.64)\end{array}$ & $\begin{array}{c}0.539 * * * \\
(5.40)\end{array}$ & $\begin{array}{c}1.000 * * * \\
(8.15)\end{array}$ & $\begin{array}{c}0.0376 \\
(0.25)\end{array}$ \\
\hline GROWTH & $\begin{array}{c}0.00230 \\
(0.03)\end{array}$ & $\begin{array}{l}-0.142 \\
(-1.53)\end{array}$ & $\begin{array}{c}-0.0333 \\
(-0.34)\end{array}$ & $\begin{array}{c}-0.0545 \\
(-0.68)\end{array}$ & $\begin{array}{l}-0.225^{*} \\
(-2.43)\end{array}$ & $\begin{array}{c}0.0542 \\
(0.36)\end{array}$ \\
\hline LOANS & $\begin{array}{l}0.542 \\
(1.78)\end{array}$ & $\begin{array}{l}0.615 \\
(1.55)\end{array}$ & $\begin{array}{l}0.466 \\
(1.00)\end{array}$ & $\begin{array}{l}0.440 \\
(1.40)\end{array}$ & $\begin{array}{l}0.297 \\
(0.76)\end{array}$ & $\begin{array}{l}0.724 \\
(1.49)\end{array}$ \\
\hline EQUITY & $\begin{array}{c}0.0370 * * * \\
(7.27)\end{array}$ & $\begin{array}{c}0.0425 * * * \\
(6.33)\end{array}$ & $\begin{array}{c}0.0388^{* * *} \\
\quad(5.02)\end{array}$ & $\begin{array}{c}0.0149 * \\
(2.34)\end{array}$ & $\begin{array}{c}0.0212 * * \\
(3.13)\end{array}$ & $\begin{array}{c}-0.0109 \\
(-0.75)\end{array}$ \\
\hline _cons & $\begin{array}{l}-2.226 \\
(-1.71) \\
\end{array}$ & $\begin{array}{c}-9.430 * * * \\
(-5.75)\end{array}$ & $\begin{array}{c}6.689^{* *} \\
(3.24)\end{array}$ & $\begin{array}{c}-4.535^{* *} \\
(-3.18)\end{array}$ & $\begin{array}{c}-10.55 * * * \\
(-6.62)\end{array}$ & $\begin{array}{l}3.288 \\
(1.39) \\
\end{array}$ \\
\hline $\begin{array}{l}\mathrm{N} \\
\mathrm{R} \text {-square }\end{array}$ & $\begin{array}{c}2,396 \\
0.1245\end{array}$ & $\begin{array}{c}1,082 \\
0.1788\end{array}$ & $\begin{array}{c}1,314 \\
0.1515\end{array}$ & $\begin{array}{c}2,385 \\
0.1497\end{array}$ & $\begin{array}{c}1,078 \\
0.1633\end{array}$ & $\begin{array}{c}1,307 \\
0.1187\end{array}$ \\
\hline
\end{tabular}

Notes: This table reports the results of a panel data regression fixed effect. Regression coefficients are reported with SE in parenthesis. The dependent variables are SHROAA and SHROAE. Overall sample (1, 4). Smaller banks $(2,5)$. Larger banks $(3,6)$. The following bank-specific control are included in the regression: ASSETS is the natural logarithm of Total Asset, GROWTH is the growth rate of bank total asset, EQUITY is the ratio of equity to total asset, LOAN is the ratio of total loans to total asset. The observation period is 2012-2019. t statistics in parentheses $* \mathrm{p}<0.05, * * \mathrm{p}<0.01, * * * \mathrm{p}<0.001$

Source: Authors' computation

Overall, Table 7 provides strong and consistent evidence that nontraditional revenue component positively affects risk-adjusted profitability, as the estimated coefficients of the share of non-traditional income is positive and highly significant. Thus, our results support the findings of Chiorazzo et al. (2008), Nguyen et al. (2015), and Saunders et al. (2016). However, this finding is in contrast with Demirgüç-Kunt and Huizinga (2010) who find, using an international sample, that banking strategies that rely prominently on generating noninterest income are very risky. Also, our results differ from several U.S. banking studies like (Stiroh, 2004b, 2004a) and Stiroh and Rumble (2006) and a study of emerging economies by Sanya and Wolfe (2011), which associates risk-reduction benefits from increased share of NIIs but no significant effect in terms of risk-adjusted profits.

As an interpretation of our results, the positive and significant coefficient on the non-interest proportion is providing evidence that banks with high non-interest income present lower risk and higher returns than those with mainly traditional interest income. Mainly, NII is less depending on overall business conditions than interest income, so an increased reliance on nontraditional activities reduces the cyclical variation in performance of banks. Otherwise, expanded product and cross-selling opportunities related with growing noninterest income may offer traditional diversification benefits for a revenue portfolio and improve the risk/return trade-off of banks (Stiroh, 2002). Therefore, bank institutions increasingly depend on noninterest income to survive and success in generating profit and revenues (Bian et al., 2015).

Finally, Table 7 demonstrates that our major empirical findings remain qualitatively unchanged. Including either a diversification index or disaggregated non-traditional income components implies a positive and statistically significant effect on a risk-adjusted performance, which reveals that our main findings remain robust and consistent.

\section{Conclusion}

In this paper, we empirically investigate the effect of income diversification, that we derive from a HerfindahlHirschman Index of specialization, on risk-adjusted return measures. To this end, we have applied a fixed-effect model to examine a sample of 49 African countries with a wider range of a panel dataset over the period between 2012 and 2019, for a total of 390 banks.

Our results provide strong evidence that DIV has shown increase in returns along with reduction in risk for African banks, confirming the hypothesis of the "portfolio diversification" effect. However, on average, the income diversification was about 36,60 percent during the sample period of $2012-2019$. In fact, since the share of non-interest income in net operating income is not high enough, small increases in the share of non-interest 
income may have still affected the risk-adjusted returns in commercial banks in Africa.

Our analysis also explores interesting new issues by considering the interactive effects among income diversification, bank size and degree of capitalization. We suggest that larger African banks are better equipped to manage the risk-earning components and that more diversified and capitalized banks are characterized by higher returns and lower risk. In our view, these results show that the regulatory policies, addressed to increase bank capitalization, lead to improve performance and banks' stability. Although, some questions remain unanswered, such as what would be the long-term effects of higher requirements. In addition, we provide empirical evidence of an inverted U-shaped relationship between size and risk-adjusted performance, which implies the existence of an optimal size. Therefore, to improve bank performance, regulators and managers should bring more attention to bank size before a diversification strategy. The given study incorporates several tests and robustness checks to verify assessing changes in diversification level by using an alternative measure of diversification and for alternative subsamples. Based on these results, we believe that income diversification plays a crucial role in determining bank performance. In fact, the relation between risk-adjusted return and noninterest income is stronger at large banks in Africa. Our results support the fact that economies of scale and the capability of investing more intensively in ICT allow larger banks to manage the operating leverage associated with fee-based transactions much better than small-sized banks (Chiorazzo et al., 2008; DeYoung \& Roland, 2001).

Thus, there are two categories of banks in Africa, larger banks and smaller banks. Large banks may have a stronger incentive to diversify their activities than small banks. In our view, large banks may have a comparative advantage in financial and insurance market. However, as smaller banks do not benefit from diversification, we suggest that small African banks could focus on traditionally established lending lines of business by fostering their client relationships (i.e., bank branch proximity), rather than on diversification for improve their riskadjusted performance.

Lastly, this study needs to be validated by other researches in the African context. In terms of methodology, some extensions can be built further, in future upon this analysis, for instance through an examination of the effects of sub-categories of non-interest income generating activities and the effect of ownership structure can also be investigated. Secondly, the study considered only risk-adjusted performance measures as a measure for bank performance, so future study should consider the measure of efficiency of diversification activities and macroeconomic factors in African banking sector.

\section{References}

Al-Tarawneh, A., Abu Khalaf, B. K., \& Assaf, G. Al. (2016). Noninterest Income and Financial Performance at Jordanian Banks. International Journal of Financial Research, 8(1), 166.

Alhassan, A. L. (2015). Income diversification and bank efficiency in an emerging market. Managerial Finance, $41(12), 1318-1335$.

Amidu, M., \& Wolfe, S. (2013). The effect of banking market structure on the lending channel: Evidence from emerging markets. Review of Financial Economics, 22(4), 146-157.

Amihud, Y., \& Lev, B. (1981). Risk Reduction As a Managerial Motive for Conglomerate Mergers. Bell Journal of Economics, 12(2), 605-617.

Apergis, N. (2015). Competition in the banking sector: New evidence from a panel of emerging market economies and the financial crisis. Emerging Markets Review, 25, 154-162.

Baele, L., De Jonghe, O., \& Vander Vennet, R. (2007). Does the stock market value bank diversification? Journal of Banking and Finance, 31(7), 1999-2023.

Beck, T., \& Cull, R. (2013). Banking in Africa. World Bank Policy Research Working Paper No. 6684 World Bank, Washington

Allen N. Berger \& J. David Cummins \& Mary A. Weiss \& Hongmin Zi, 1999. "Conglomeration versus strategic focus: evidence from the insurance industry," Finance and Economics Discussion Series 1999-40, Board of Governors of the Federal Reserve System (U.S.).

Berger, A. N., Hasan, I., \& Zhou, M. (2010). The effects of focus versus diversification on bank performance: Evidence from Chinese banks. Journal of Banking and Finance, 34(7), 1417-1435.

Bian, W. L., Wang, X. N., \& Sun, Q. X. (2015). Non-interest Income, Profit, and Risk Efficiencies: Evidence from Commercial Banks in China. Asia-Pacific Journal of Financial Studies, 44(5), 762-782.

Boadi, I. (2018). African Entrepreneurship. In African Entrepreneurship.

Boyd, J. H., \& Graham, S. L. (1986). Risk, Regulation, and Bank Holding Company Expansion Into Nonbanking. Quarterly Review, 10(2).

Brahmana, R., Kontesa, M., \& Gilbert, R. E. (2018). Income diversification and bank performance: Evidence from Malaysian banks. Economics Bulletin, 38(2), 799-809.

Brighi, P., \& Venturelli, V. (2014). How do income diversification, firm size and capital ratio affect performance? Evidence for bank holding companies. Applied Financial Economics, 24(21), 1375-1392. 
Chiorazzo, V., Milani, C., \& Salvini, F. (2008). Income diversification and bank performance: Evidence from Italian banks. Journal of Financial Services Research, 33(3), 181-203.

Chronopoulos, D. K., Liu, H., McMillan, F. J., \& Wilson, J. O. S. (2015). The dynamics of US bank profitability. European Journal of Finance, 21(5), 426-443.

Claessens, S., \& Van Horen, N. (2014). Foreign banks: Trends and impact. Journal of Money, Credit and Banking, 46(SUPPL.1), 295-326.

De Jonghe, O. (2010). Back to the basics in banking? A micro-analysis of banking system stability. Journal of Financial Intermediation, 19(3), 387-417.

Demirgüç-Kunt, A., \& Huizinga, H. (2010). Bank activity and funding strategies: The impact on risk and returns. Journal of Financial Economics, 98(3), 626-650.

Demsetz, R. S., \& Strahan, P. E. (1997). Diversification, Size, and Risk at Bank Holding Companies. Journal of Money, Credit and Banking, 29(3), 300.

Deng, S., \& Elyasiani, E. (2008). Geographic diversification, bank holding company value, and risk. Journal of Money, Credit and Banking, 40(6), 1217-1238.

Deyoung, R., \& Rice, T. (2004). DeYoung_et_al-2004-Financial_Review.pdf. 39, 101-127.

DeYoung, R., \& Roland, K. P. (2001). Product Mix and Earnings Volatility at Commercial Banks: Evidence from a Degree of Leverage Model. In SSRN Electronic Journal.

Drucker, S., \& Puri, M. (2009). On loan sales, loan contracting, and lending relationships. Review of Financial Studies, 22(7), 2835-2872.

Elsas, R., Hackethal, A., \& Holzhäuser, M. (2010). The anatomy of bank diversification. Journal of Banking and Finance, 34(6), 1274-1287.

Guerry, N., \& Wallmeier, M. (2017). Valuation of diversified banks: New evidence. Journal of Banking and Finance, 80, 203-214.

Honohan, P., \& Beck, T. (2007). Making finance work for Africa, World bank.

Ismail, A., Hanif, R., Choudhary, S., \& Nisar, A. (2015). Income-Diversification In Banking Sector Of Pakistan: A "blessing" Or "curse"? The Journal of Commerce, 7(1), 11-22.

Jensen, M. C. (1986). Agency costs of free cash flow, corporate finance, and takeovers. Corporate Bankruptcy, 76(2), 11-16.

Klein, P. G., \& Saidenberg, M. R. (1997). Diversification, Organization, and Efficiency: Evidence from Bank Holding Companies. SSRN Electronic Journal, February.

Laeven, L., \& Levine, R. (2007). Is there a diversification discount in financial conglomerates? Journal of Financial Economics, 85(2), 331-367.

Léon, F. (2016). Does the expansion of regional cross-border banks affect competition in Africa? Indirect evidence. Research in International Business and Finance, 37(October), 66-77.

Lepetit, L., Nys, E., Rous, P., \& Tarazi, A. (2008). The expansion of services in European banking: Implications for loan pricing and interest margins. Journal of Banking and Finance, 32(11), 2325-2335.

Mercieca, S., Schaeck, K., \& Wolfe, S. (2007). Small European banks: Benefits from diversification? Journal of Banking and Finance, 31(7), 1975-1998.

Meslier, C., Tacneng, R., \& Tarazi, A. (2014). Is bank income diversification beneficial? Evidence from an emerging economy. Journal of International Financial Markets, Institutions and Money, 31(1), 97-126.

Nguyen, M., Perera, S., \& Skully, M. (2016). Bank market power, ownership, regional presence and revenue diversification: Evidence from Africa. Emerging Markets Review, 27, 36-62.

Nguyen, T. C., Vo, D. V., \& Nguyen, V. C. (2015). Risk and Income Diversification in The Vietnamese Banking System. Journal of Applied Finance \& Banking, 5(1), 93-109.

Nurullah, M., \& Staikouras, S. K. (2008). The Separation of Banking from Insurance: Evidence from Europe. Multinational Finance Journal, 12(3/4), 157-184.

Olarewaju, O. M. (2017). Operational Diversification and Financial Performance of Sub- Saharan Africa Commercial Banks: Static and Dynamic Approach. Acta Universitatis Danubius : Oeconomica, 13(5), 84106.

Pennathur, A. K., Subrahmanyam, V., \& Vishwasrao, S. (2012). Income diversification and risk: Does ownership matter? An empirical examination of Indian banks. Journal of Banking and Finance, 36(8), 2203-2215.

Sahoo, D., \& Mishra, P. (2012). Operational Diversification and Stability of Financial Performance in Indian Banking Sector : A Panel Data Investigation. 3(3), 70-88.

Sanya, S., \& Wolfe, S. (2011). Can Banks in Emerging Economies Benefit from Revenue Diversification? Journal of Financial Services Research, 40(1), 79-101.

Saunders, A., Schmid, M., \& Walter, I. (2016). Non-interest income and bank performance : does ring-f encing reduce bank risk? Swiss institute of banking and finance ( $\mathrm{s} / \mathrm{bf}-\mathrm{hsg}$ ) this version : march 2016 noninterest income and bank performance : Does Ring-Fencing Reduce Bank . 
Saunders, A., \& Walter, I. (1994). Universal Banking in the United States: What Could We Gain? What Could We Lose? Southern Economic Journal, 61(1), 231.

Shweta, S., \& Anand, A. (2018). Income diversification and bank performance: evidence from BRICS nations. International Journal of Productivity and Performance Management, 67(9), 1625-1639.

Stiroh, K. J. (2004a). Diversification in Banking: Is Noninterest Income the Answer? SSRN Electronic Journal.

Stiroh, K. J. (2004b). Do Community Banks Benefit from Diversification? Journal of Financial Services Research, 2001, 135-160.

Stiroh, K. J., \& Rumble, A. (2006). The dark side of diversification: The case of US financial holding companies. Journal of Banking and Finance, 30(8), 2131-2161.

Trujillo-Ponce, A. (2013). What determines the profitability of banks? Evidence from Spain. Accounting and Finance, 53(2), 561-586. 